\title{
ANALISIS PERMINTAAN PANGAN DAN NONPANGAN RUMAH TANGGA DENGAN GANGGUAN KESEHATAN DI INDONESIA
}

\author{
Muhammad Syafiudin ${ }^{1}$, Turro S. Wongkaren ${ }^{2}$ \\ ${ }^{1}$ Badan Pusat Statistik, ${ }^{2}$ Universitas Indonesia \\ e-mail:, ${ }^{1}$ apikudin@ bps.go.id
}

\begin{abstract}
Abstrak
Penelitian ini bertujuan menganalisis dampak tidak langsung gangguan kesehatan terhadap permintaan pangan dan non pangan rumah tangga. Dengan menggunakan data Susenas Panel tahun 2012 dan 2013 dan menerapkan two step heckman selection model untuk estimasi pendapatan dan seemingly unrelated regression estimator untuk estimasi konsumsi rumah tangga. Hasilnya menunjukkan bahwa gangguan kesehatan kepala rumah tangga akan menurunkan pendapatannya. Dampak ini akan lebih dirasakan oleh rumah tangga perempuan miskin dan bekerja di sektor pertanian. Penurunan pendapatan ini menyebabkan porsi pengeluaran konsumsi non pangan menurun, khususnya untuk pengeluaran pemeliharaan perumahan, namun pengeluaran untuk perawatan tubuh justru meningkat. Sedangkan untuk porsi konsumsi pangan tidak terpengaruh. Hal ini menunjukkan bahwa, gangguan kesehatan dapat menyebabkan penurunan tingkat kesejahteraan rumah tangga karena menyebabkan penurunan pendapatan dan peningkatan pengeluaran kesehatan. Oleh karena itu, diperlukan kebijakan yang dapat melindungi kesejahteraan rumah tangga ketika mengalami gangguan kesehatan, bisa berupa subsidi biaya kesehatan atau cash transfer.
\end{abstract}

Kata kunci: Gangguan Kesehatan, Konsumsi, Pangan, Non Pangan, Pendapatan Rumah Tangga

\begin{abstract}
This study aims to analyze the indirect effects of health problems on household food and non-food demand. This research uses Susenas Panel data for 2012 and 2013 and applies the 'two step heckman selection model' to estimate income, and 'seemingly unrelated regression estimator' to estimate household consumption. The results show that health issues or problems of the household will decrease their income. This impact will be worse experienced by the poor female household and work in the agricultural sector. The decrease in income has led to a decrease in non-food expenditure, especially on housing maintenance; but on the contrary, expenditure for body care has increased. However, it has not affected the expenditure on food consumption. This finding shows that health problems would be lowering household welfare as decreasing income and increasing health expenditure. Therefore, it is necessary to formulate policies to protect household welfare directly affected by health problems, for example by providing health subsidy or cash transfer.
\end{abstract}

Keywords: illhealth, illness, consumption, food and Non-food, household income 


\section{PENDAHULUAN}

Sebagai salah satu agen ekonomi, tingkat kesejahteraan rumah tangga sangat rentan terhadap fluktuasi tingkat pendapatan. Salah satu penyebabnya adalah gangguan kesehatan (ill health) yang dialami oleh anggota rumah tangga (Gertler \& Gruber, 2002). Menurut Genoni (2012), terdapat biaya ekonomi yang harus ditanggung individu atau rumah tangga ketika mengalami gangguan kesehatan yaitu pertama, gangguan kesehatan membatasi kemampuan individu untuk bekerja dan kedua dapat menimbulkan tambahan pengeluaran untuk perawatan kesehatan.

Di negara berkembang, dimana pada umumnya cakupan program jaminan kesehatan masih relatif rendah, dampak gangguan kesehatan terhadap kesejahteraan bisa lebih besar (Russell, 2004; Wagstaff, 2007). Hal ini terjadi karena rumah tangga harus menanggung sebagian besar biaya pelayanan kesehatan yang harus dikeluarkan (Out of Pocket). Dimana jumlahnya bisa sangat besar dan membebani perekonomian rumah tangga. Sehingga hal ini bisa menjadi salah satu pemicu terjadinya kemiskinan (Hoogeveen, Tesliuc, Vakis, \& Dercon, 2004).

Sebagai salah satu negara berkembang, hal ini juga terjadi di Indonesia. Hak setiap warga negara untuk mendapatkan pelayanan kesehatan yang baik merupakan tanggung jawab negara. Sebagaimana telah di atur di dalam Undang-undang Dasar 1945 amandemen keempat pasal $28 \mathrm{H}$ (1). Namun pada implementasinya, pelaksanaan amanat undang-undang tersebut masih belum berjalan dengan baik. Meskipun sejak awal tahun 2014 pemerintah telah menjalankan Program Jaminan Kesehatan Nasional (JKN), yang merupakan salah satu implementasi dari Undang-Undang Dasar 1945 tersebut. Namun dalam pelaksanaannya masih banyak ditemui kekurangan baik pada kualitas pelayanan maupun kuantitasnya yang belum menjangkau seluruh penduduk di Indonesia.
Berdasarkan data Kementerian Kesehatan Republik Indonesia hingga akhir tahun 2016 cakupan kepesertaan Jaminan Kesehatan Nasional (JKN) baru mencapai 66,46 persen. Dan berdasarkan hasil riset kesehatan dasar tahun 2013 (Riskesdas 2013), dari seluruh rumah tangga pada kuintil terbawah berdasarkan indeks kepemilikan, baru sekitar 37,1 persen yang mendapatkan pelayanan kesehatan gratis. Dari sisi pembiayaannya, 53,5 persen dari seluruh rawat inap dan 67,9 persen dari seluruh rawat jalan masih menggunakan biaya sendiri (Riskesdas 2013). Itu artinya sumber biaya yang digunakan untuk semua fasilitas kesehatan di Indonesia masih didominasi oleh biaya sendiri (out of pocket).

Padahal berdasarkan laporan The Global Medical Trend Survey Report yang dirilis oleh Tower Watson \& Co, biaya kesehatan di Indonesia terus meningkat dan peningkatannya selalu berada diatas tingkat inflasi umum. Pada tahun 2012 biaya kesehatan di Indonesia meningkat sebanyak $11,5 \%$, kemudian melonjak menjadi $12,5 \%$ pada tahun 2013. Kenaikan ini melebihi tingkat inflasi secara umum yang hanya sebesar $4,3 \%$ pada tahun 2012 dan $8,4 \%$ pada tahun 2013. Sehingga tidak membuat heran jika masalah gangguan kesehatan dapat menjadi sebuah ancaman serius bagi kesejahteraan rumah tangga di Indonesia.

Berdasarkan World Statistic Health 2018 yang diterbitkan oleh WHO, pada tahun 2015 terdapat sebanyak 3,3 persen dari total penduduk di Indonesia memiliki pengeluaran untuk kesehatan lebih dari 10 persen dari total pendapatan yang dimiliki, dengan rata-rata pengeluaran kesehatan perkapita sebesar US\$ 112. Sebuah nilai yang cukup besar khususnya bagi rumah tangga ekonomi menengah kebawah. Dimana sebagian besar pendapatan mereka dialokasikan untuk kebutuhan konsumsi sehari-hari, khususnya konsumsi pangan.

Padahal disisi lain, gangguan kesehatan yang dialami akan menyebabkan penurunan pendapatan. Gertler \& Gruber (2002) dalam penelitiannya di Indonesia menemukan bahwa, gangguan kesehatan yang dialami oleh kepala rumah tangga 
akan menyebabkan penurunan penawaran kerja sehingga berdampak terhadap penurunan pendapatan rumah tangga. Kedua hal ini tentu akan menjadi beban ekonomi bagi rumah tangga, terjadi peningkatan pengeluaran untuk kesehatan dan disaat yang sama terjadi penurunan pendapatan, tentu hal ini akan mempengaruhi tingkat konsumsi rumah tangga.

Namun demikian, dari beberapa hasil penelitian terdahulu, pengaruh gangguan kesehatan terhadap tingkat konsumsi rumah tangga menunjukkan hasil yang beragam bahkan saling bertolak belakang. Misalnya penelitian yang dilakukan oleh Cochrane (1991) dan Townsend (1994) menunjukkan bahwa, tingkat konsumsi rumah tangga tidak terpengaruh oleh gangguan kesehatan yang dialami oleh rumah tangga. Sedangkan Gertler \& Gruber (2002) dan Sparrow et al. (2014) justru menunjukkan bahwa gangguan kesehatan yang dialami rumah tangga akan mempengaruhi tingkat konsumsi rumah tangga karena adanya peningkatan pengeluaran untuk kesehatan. Sementara itu Asfaw \& Braun (2004), justru menunjukkan bahwa gangguan kesehatan tidak sepenuhnya mempengaruhi konsumsi rumah tangga. Menurutnya secara total, tingkat konsumsi rumah tangga tidak terpengaruh oleh gangguan kesehatan. Gangguan kesehatan hanya mempengaruhi konsumsi rumah tangga secara parsial yaitu hanya pada konsumsi pangan yang dibeli oleh rumah tangga.

Genoni (2012) berpendapat bahwa perbedaan hasil penelitian ini terjadi karena rumitnya mengidentifikasi dan mengukur dampak dari gangguan kesehatan. Menurut Strauss \& Thomas (1998) kesehatan adalah sesuatu yang multidimensi, sehingga sebuah indikator kesehatan tidak mungkin dapat menangkap semua dampak yang ditimbulkan, karena bisa saja setiap indikator kesehatan memiliki dampak yang berbeda terhadap individu atau rumah tangga. Oleh karena itu, untuk mengukur dampak gangguan kesehatan terhadap tingkat konsumsi rumah tangga harus dimulai dengan mendefinisikan gangguan kesehatan tersebut. Oleh karena itu, dengan mengadaptasi penelitian Cochrane, (1991) \& Sparrow et al., (2014) dalam mendefinisikan gangguan kesehatan, maka penelitian ini mendefinisikan gangguan kesehatan dengan menggunakan lama hari aktifitas sehari-hari terganggu karena keluhan kesehatan yang dialami . Definisi gangguan kesehatan ini bersifat umum dan tidak terbatas pada suatu gejala gangguan kesehatan tertentu. Namun tetap dapat menggambarkan biaya ekonomi yang akan ditanggung akibat gangguan kesehatan yang dialami sebagaimana yang dimaksud oleh Genoni (2012), yaitu berupa penurunan pendapatan akibat penurunan penawaran kerja karena gangguan kesehatan.

Selain itu, untuk mengukur dampak dari gangguan kesehatan terhadap tingkat konsumsi rumah tangga, maka bagaimana mekanisme gangguan kesehatan mempengaruhi konsumsi rumah tangga juga penting untuk diketahui. Sehingga analisa dampak gangguan kesehatan terhadap tingkat konsumsi yang dihasilkan akan lebih baik karena dapat melihat dampak dari setiap proses yang terjadi dari mekanisme tersebut. Menurut Nguyet \& Mangyo (2010), penyebab utama terjadinya penurunan tingkat konsumsi adalah akibat penurunan pendapatan. Sehingga dalam hal ini penurunan pendapatan merupakan intermediate relationship antara gangguan kesehatan dan tingkat konsumsi.

Oleh karena itu, untuk mengukur dampak gangguan kesehatan terhadap tingkat konsumsi, maka penelitian ini memulainya dengan mengukur dampak gangguan kesehatan terhadap tingkat pendapatan, kemudian melihat bagaimana dampak perubahan tingkat pendapatan tersebut terhadap tingkat konsumsi rumah tangga. Sehingga dalam hal ini gangguan kesehatan memiliki dampak tidak langsung terhadap tingkat konsumsi rumah tangga. Dimana pada penelitian-penelitian sebelumnya, gangguan kesehatan dianggap berpengaruh langsung terhadap perubahan tingkat konsumsi rumah tangga, sehingga bagaimana mekanisme gangguan kesehatan mempengaruhi gangguan kesehatan belum dapat dijelaskan dengan baik (lihat Asfaw 
\& Braun (2004), Wang, Zhang, \& Hsiao (2006); Wagstaff (2007); Nguyet \& Mangyo (2010) dan Sparrow et al. (2014)).

Selain itu, menurut data BPS, dalam sepuluh tahun terakhir persentase penduduk miskin di Indonesia telah mengalami penurunan cukup signifikan yaitu dari 15,42 persen pada tahun 2008 menjadi sebesar 9,66 persen tahun 2018. Meskipun secara total mengalami penurunan yang cukup besar, namun jika dilihat berdasarkan lapangan usaha yang dilakoni, maka tingkat kemiskinan di Indonesia masih didominasi oleh rumah tangga pertanian. Sedangkan berdasarkan jenis kelamin kepala rumah tangga, penurunan tingkat kemiskinan pada rumah tangga perempuan (RTP) lebih lambat daripada rumah tangga laki-laki (RTL). Dari kedua fakta miris ini, menarik untuk dikaji bagaimana pola konsumsi rumah tangga, ketika mereka sudah dalam kondisi sulit secara ekonomi, namun harus mengalami fluktuasi pendapatan, dimana salah satunya karena gangguan kesehatan (Gertler \& Gruber, 2002). Sehingga dengan demikian, penelitian ini akan menguji secara empiris hipotesis hubungan antara gangguan kesehatan dan tingkat konsumsi dengan memperhatikan hubungan tidak langsung diantara keduanya dan kemudian mengkaitkannya dengan isu kemiskinan yang terjadi di Indonesia ini.

\section{TINJAUAN REFERENSI}

\section{Teori Penawaran Kerja dan Pendapatan Rumah Tangga}

Teori penawaran kerja individu di dalam rumah tangga merupakan pengembangan dari teori permintaan neoklasik yaitu dengan menambahkan waktu bersantai (leisure) sebagai salah satu barang yang dikonsumsi oleh rumah tangga. Dengan asumsi bahwa leisure dan barang yang dikonsumsi baik makanan $\left(X_{1}\right)$ maupun non-makanan dan jasa $\left(X_{2}\right)$ adalah barang normal, dan rumah tangga akan mendapatkan kepuasan (utility) ketika mengkonsumsi leisure $(L)$ kedua jenis barang tersebut. Maka Fungsi utilitas dari mengkonsumsi kedua barang tersebut dapat dituliskan sebagai berikut:

$$
U=U\left(L, X_{1}, X_{2} ; \tau\right)
$$

Semakin banyak leisure atau barang yang dikonsumsi, maka tingkat kepuasan yang diperoleh semakin tinggi. Namun tingkat konsumsi seseorang terhadap barang/jasa dan leisure dibatasi oleh waktu dan tingkat pendapatan yang dimiliki. Tingkat pendapatan seseorang terdiri dari pendapatan upah (labor income) dan pendapatan non upah (Non Labor Income). Dan semua pendapatan yang dimiliki rumah tangga ini akan digunakan oleh rumah tangga untuk membeli $\mathrm{X}_{1}$ dan $\mathrm{X}_{2}$ pada tingkat harga $\mathrm{P}_{1}$ dan $\mathrm{P}_{2}$. Sehingga fungsi pendapatan individu menjadi sebagai berikut

$F=W \cdot h+V=P_{1} \cdot X_{1}+P_{2} \cdot X_{2}$

Jika tingkat upah adalah tetap dan waktu setiap orang habis untuk bekerja $(h)$ dan bersantai (L), maka total waktu yang dimiliki menjadi $(T=L+h)$. Maka persamaan (2) dapat ditulis menjadi

$$
F=\underset{X_{2}}{W} \cdot T+V=W \cdot L+P_{1} \cdot X_{1}+P_{2} .
$$

maka persamaan (3) adalah persamaan Beckerian full income constraint.

Dengan menggunakan fungsi lagrange maka kita dapat memaksimumkan fungsi kepuasan pada persamaan (1) dengan kendala anggaran pada persamaan (3), sehingga menjadi sebagai berikut

$$
\begin{aligned}
\max \mathcal{L}= & U\left(L, X_{1}, X_{2}\right)+\lambda(W \cdot T+ \\
& V-W \cdot L-P_{1} \cdot X_{1}-P_{2} . \\
& \left.X_{2}\right)
\end{aligned}
$$

Dengan menggunakan first order condition dari persamaan (4) akan diperoleh reduce form dari persamaan penawaran jam kerja $\left(S_{h}\right)$ dan persamaan permintaan barang dan jasa rumah tangga $\left(D_{X_{i}}\right)$ berikut.

$$
\begin{aligned}
h^{*}= & T-L^{*}=S_{h}\left(W, P_{1}, P_{2}, V, \tau\right)= \\
& S_{h}\left(W, P_{1}, P_{2}, F, \tau\right) \\
X_{i}^{*}= & D_{X_{i}}\left(W, P_{i}, V, \tau\right)= \\
& D_{X_{i}}\left(W, P_{i}, F, \tau\right), \quad i=1,2
\end{aligned}
$$

Persamaan (5) dan (6) merupakan fungsi dari tingkat upah (W), tingkat harga $\left(\mathrm{P}_{1}\right.$ dan $\left.\mathrm{P}_{2}\right)$ dan tingkat pendapatan ( $V$ atau $F)$. Dengan asumsi bahwa leisure dan barang atau jasa yang dikonsumsi tersebut adalah barang normal, maka tingkat 
konsumsi dan tingkat pendapatan berhubungan positif $\left(\partial X_{i} / \partial F>0\right)$, dimana tingkat pendapatan tersebut ditentukan oleh jumlah jam kerja yang ditawarkan, semakin tinggi jam kerja yang ditawarkan, maka semakin tinggi tingkat pendapatan yang bisa dihasilkan $(\partial F / \partial h)>0)$. Dalam konteks penelitian ini, ketika individu mengalami gangguan kesehatan akan menyebabkan penurunan jam kerja sehingga akan berdampak negatif terhadap tingkat pendapatan. Penurunan tingkat pendapatan ini akan berpengaruh negatif terhadap tingkat konsumsi rumah tangga. Sehingga secara tidak langsung, gangguan kesehatan akan berdampak negatif terhadap tingkat konsumsi rumah tangga melalui penurunan pendapatan.

\section{Teori Added Worker Effect}

Sebagai salah satu agen ekonomi, rumah tangga memiliki tujuan untuk memaksimumkan kepuasan seluruh anggota rumah tangga dengan asumsi bahwa kepuasan tersebut diperoleh melalui konsumsi dan waktu bersantai (leisure) dari setiap anggota rumah tangga dan tingkat pendapatan dan tingkat pengeluaran rumah tangga merupakan akumulasi dari semua anggota rumah tangga, maka rumah tangga akan berusaha memaksimumkan kepuasannya dengan kendala pendapatan dari seluruh anggota rumah tangga (Family Utility Budget Constrait Model). Ashenfelter \& Heckman (1974) memodelkan tujuan dan kendala yang dimiliki rumah tangga ini menjadi sebagai berikut:

$$
\operatorname{Max} U=U\left(L_{m}, L_{f}, X\right)
$$

Jika $L_{m}$ dan $L_{f}$ adalah waktu yang dihabiskan diluar pasar tenaga kerja (Non Work Time) yang dilakukan oleh anggota rumah tangga laki-laki dan perempuan. Sedangkan $\mathrm{X}$ adalah komposit dari seluruh barang yang dikonsumsi oleh rumah tangga dengan asumsi bahwa tidak ada perubahan harga pada seluruh barang tersebut. Maka untuk memaksimumkan kepuasannya maka rumah tangga terkendala pada anggaran pendapatan yang dimiliki

$$
\begin{aligned}
& W_{m} T+W_{f} T+V=W_{m} L_{m}+ \\
& W_{f} L_{f}+P X
\end{aligned}
$$

$W_{m}$ dan $W_{f}$ adalah tingkat upah yang diterima oleh anggota rumah tangga, $V$ adalah pendapatan non-upah. Sedangkan $P$ adalah tingkat harga dari barang-barang yang dikonsumsi, $T$ adalah total waktu yang dimiliki oleh setiap anggota rumah tangga yang diasumsikan bahwa alokasi waktu hanya digunakan untuk bekerja dan bersantai (leisure). Sehingga waktu untuk bekerja untuk setiap anggota rumah tangga adalah $h_{i}=T-L_{i}, i=m$, $f$. Maka sisi kiri persamaan (8) adalah total pendapatan rumah tangga yang merupakan akumulasi dari seluruh pendapatan anggota rumah tangga yang bekerja, sedangkan sisi kanannya adalah total pengeluaran rumah tangga. Sehingga persamaan (8) diatas akan menjadi:

$$
\begin{aligned}
& W_{m}\left(T-L_{m}\right)+W_{f}\left(T-L_{f}\right)+V= \\
& P X
\end{aligned}
$$

Persamaan (9) menunjukkan bahwa total pendapatan sama dengan total pengeluaran. Maka dengan menggunakan lagrange multiplier dan first order condition untuk memaksimumkan fungsi utilitas (7) dengan kendala fungsi anggaran pada persamaan (8), akan diperoleh bentuk reduce form dari persamaan penawaran kerja dari setiap anggota rumah tangga $\left(h_{i}\right)$ yang merupakan fungsi dari tingkat harga, tingkat upah dan pendapatan non upah yang diterima oleh rumah tangga.

$$
h_{i}=R_{i}\left(W_{m}, W_{f}, P, V\right)
$$

Dari persamaan ini bisa dilihat bahwa fungsi penawaran kerja salah satu anggota rumah tangga akan dipengaruhi oleh tingkat upah anggota rumah tangga yang lain.

Menururt Ashenfelter \& Heckman (1974) perubahan penawaranan kerja salah satu anggota rumah tangga akibat perubahan tingkat upah anggota rumah tangga yang lain terjadi karena adanya efek substitusi dan efek pendapatan. Efek substitusi terdiri atas dua macam yaitu pertama perubahan penawaran kerja karena perubahan tingkat upah pada diri sendiri (own substitution effect) yang bernilai 
positif $\left(S_{i i}\right)$ dan efek susbstitusi yang kedua terjadi karena terjadinya perubahan tingkat upah anggota rumah tangga yang lain (cross Substitution Effect) yang bisa bernilai positif atau negatif $\left(S_{i j}\right)$, tergantung pada hubungan jam kerja antar anggota rumah tangga, apakah bersifat saling menggantikan (substitusi) atau melengkapi (komplementer).

$$
\begin{aligned}
& S_{i i}>0,(i=m, f) \\
& \frac{d h_{i}}{d W_{j}}=S_{i j}+R_{j} \frac{d R_{i}}{d V}
\end{aligned}
$$

Sedangkan perubahan penawaran kerja karena efek pendapatan $\left(R_{j} \frac{d R_{i}}{d V}\right)$ selalu bernilai negatif. Hal ini karena diasumsikan bahwa peningkatan pendapatan non-upah (Non Labor Income) dirumah tangga akan menurunkan penawaran kerja anggota rumah tangga. Oleh karena itu, jika tidak ada cross Substitution Effect, maka perubahan penawaran kerja anggota rumah tangga ke$i$ karena perubahan tingkat upah anggota rumah tangg ke- $j$ hanya akan dipengaruhi oleh efek pendapatan yang bernilai negatif. Sehingga dapat disimpulkan bahwa terdapat hubungan negatif antara peningkatan penawaran kerja salah satu anggota rumah tangga dengan perubahan tingkat upah anggota rumah tangga yang lain.

Karena itu dalam konteks adanya gangguan kesehatan yang menimpa salah satu anggota rumah tangga yang menyebabkan penurunan penawaran kerjanya sehingga menyebabkan penurunan tingkat pendapatan, maka hal ini akan direspon oleh anggota rumah tangga yang lain dengan cara meningkatkan penawaran kerjanya sebagai kompensasi penurunan penawaran kerja anggota rumah tangga yang mengalami gangguan kesehatan tersebut, sehingga secara total pendapatan rumah tangga tetap bisa dipertahankan. Konsep ini dikembangkan oleh Mincer (1962) di dalam Maloney (1987) dan dikenal dengan Added Worker Effect (AWE).

\section{Hukum Engel dan Pangsa Pengeluaran Pangan}

Dalam ilmu ekonomi, terdapat hukum yang menjelaskan hubungan antara tingkat pendapatan dan tingkat konsumsi rumah tangga, yaitu hukum Engel yang dipopulerkan oleh seorang ahli statistik dari Jerman (1821-1896). Hukum Engel menyatakan bahwa ketika pendapatan meningkat maka porsi pengeluaran untuk konsumsi pangan akan semakin menurun sedangkan porsi untuk konsumsi non pangan akan meningkat. Hukum Engel tidak menyatakan bahwa ketika pendapatan meningkat maka akan terjadi penurunan tingkat konsumsi pangan. Namun yang terjadi adalah peningkatan pengeluaran untuk konsumsi pangan lebih lambat dibandingkan dengan peningkatan pendapatan. Hal ini menyebabkan elastisitas pendapatan terhadap makanan adalah inelastis karena nilai elastisitasnya berada diantara 0 dan 1 . Sehingga dalam hal ini terdapat pergeseran porsi pengeluaran antara konsumsi pangan dan non pangan ketika terjadi perubahan pendapatan.

Salah satu penerapan hukum Engel adalah untuk melihat standar hidup suatu negara. Negara yang lebih miskin, akan memiliki koefisien Engel yang lebih besar. Artinya secara umum pengeluaran didalam negara tersebut masih didominasi oleh konsumsi pangan. Dan ini biasa terjadi pada negara-negara miskin. Namun sebaliknya, jika koefisien Engel lebih kecil, maka negara tersebut cenderung memiliki standar hidup yang lebih tinggi. Dalam penelitian ini, negara diidentikkan dengan rumah tangga. Hukum Engel merupakan penemuan empiris yang sangat konsisten. Menurut (Muellbauer, 1980), porsi (share) pengeluaran konsumsi untuk pangan terhadap total pengeluaran dapat dijadikan indikator tidak langsung terhadap tingkat kesejahteraan.

\section{METODE ANALISIS}

\section{Sumber Data}

Penelitian ini menggunakan data yang bersumber dari Survei Sosial Ekonomi Nasional (SUSENAS) triwulan pertama tahun 2012 sampai dengan 2013 yang dilakukan oleh Badan Pusat Statistik. Survei ini dilakukan pada sampel rumah 
tangga terpilih di seluruh wilayah Indonesia hingga level kabupaten/kota. Pada periode survei ini, sampel rumah tangga dipilih secara acak dan didata secara longitudinal, artinya rumah tangga yang sama akan di data kembali setiap tahun selama periode survei. Observasi penelitian ini yaitu seluruh rumah tangga sampel terpilih yang dapat ditemui pada saat pendataan pada dua periode survei, dengan jumlah observasi sebanyak 6.893 rumah tangga. Data tahun 2012 digunakan untuk mendapatkan informasi tentang kejadian gangguan kesehatan yang dialami oleh kepala rumah tangga pada periode sebelumnya yang diduga mempengaruhi tingkat pendapatan tahun 2013.

Untuk mengatasi adanya data pendapatan yang kosong, maka kekosongan data tersebut diimputasi dengan mengikuti cara yang dilakukan oleh (Gertler \& Gruber, 2002) yaitu dengan menggunakan rata-rata pendapatan kepala rumah tangga pada setiap propinsi berdasarkan jenis kelamin, kelompok umur $(<25,25-49,50+)$ dan tingkat pendidikan (lama sekolah $=0$ (tidak berpendidikan), 1 thn $<=$ lama sekolah $<=5$ tahun, lama sekolah $=6$ tahun dan lama sekolah $>=7$ thn). Bagi kepala rumah tangga yang tidak memiliki data pendapatan maka akan diimputasi dengan data rata-rata pendapatan yang sesuai karakteristik tersebut pada setiap propinsi.

\section{Model Empiris}

Model empiris yang digunakan dalam penelitian ini terdiri dari persamaan pendapatan kepala rumah tangga dan persamaan konsumsi rumah tangga. Metode analisis yang digunakan dalam penelitian ini dilakukan dengan dua tahap yaitu tahap pertama estimasi pendapatan kepala rumah tangga dan tahap kedua estimasi konsumsi rumah tangga.

\section{Persamaan Pendapatan Kepala Rumah Tangga}

Unit analisis pada persamaan ini adalah kepala rumah tangga yang mengalami gangguan kesehatan pada tahun 2012 dan 2013. Sehingga dalam hal ini, pemilihan sampel kepala rumah tangga tersebut menjadi tidak acak sehingga dapat menyebabkan hasil estimasi menjadi bias (sample selection bias). Untuk mengatasi ini, maka digunakan metode estimasi two step heckman selection model, yaitu dengan menambahkan variabel bebas IMR (Invers Mills Ratio) pada model utama. Tahap pertama metode estimasi ini yaitu dengan menghitung peluang kepala rumah tangga mengalami gangguan kesehatan dengan menggunakan model probit, dimana variabel terikat yang digunakan yaitu variabel dummy apakah kepala rumah tangga mengalami gangguan kesehatan atau tidak selama dua periode survei. Sedangkan variabel bebas yang digunakan berupa karakteristik kepala rumah tangga dan kondisi perumahan tempat tinggal yang dapat mempengaruhi peluang kepala rumah tangga mengalami gangguan kesehatan. Sehingga model probit yang digunakan adalah sebagai berikut:

$$
P_{i}=\frac{1}{1+e^{-Z_{i}}}=\frac{e^{Z_{i}}}{1+e^{Z_{i}}} \quad \text { dimana } \quad Z_{i}=
$$

$\alpha_{i}+\sum_{\boldsymbol{k}} \boldsymbol{\beta}_{\boldsymbol{k}} \boldsymbol{X}_{\boldsymbol{i} \boldsymbol{k}}+\boldsymbol{\varepsilon}_{\boldsymbol{i}}, \boldsymbol{i}$ adalah kepala rumah tangga ke- $i$, sedangkan $\boldsymbol{X}_{\boldsymbol{i} \boldsymbol{k}}$ adalah variabel bebas ke- $k$ (yaitu berupa umur, jenis kelamin, lama sekolah, jam kerja, luas lantai tempat tinggal, kepemilikan toilet dan kepemilikan akses listrik) dari kepala rumah tangga ke-i. Dari hasil estimasi ini maka diperoleh estimasi peluang kepala rumah tangga mengalami gangguan kesehatan $\left(\widehat{P}_{l}\right)$, sehingga nilai IMR diperoleh dengan membagi nilai probability density function (PDF) dengan cumulative distribution function (CDF) dalam distribusi standar normal, dengan rumus:

$$
\begin{gathered}
I M R_{i}= \\
\left(\frac{1}{\sqrt{2 \pi}} e^{\frac{-p^{2}}{2}}\right) /\left(\frac{1}{\sqrt{2 \pi}} \int_{-\sim}^{Z_{i}} e^{\frac{-p^{2}}{2}} d p\right)
\end{gathered}
$$

Nilai IMR inilah yang akan menjadi salah satu variabel bebas pada persamaan pendapatan kepala rumah tangga pada persamaan 14. Sehingga dengan menggunakan metode ini maka bias yang terjadi karena pemilihan sampel dapat dikoreksi dan estimasi yang dihasilkan menjadi lebih baik.

Selanjutnya yaitu estimasi persamaan pendapatan kepala rumah tangga pada persamaan 14. Variabel terikat yang digunakan adalah nilai pendapatan kepala 
rumah tangga selama sebulan terakhir dari pekerjaan utama pada tahun 2013 dan dinyatakan dalam bentuk logaritma dari pendapatan ril perbulan . Sehingga secara umum persamaan pendapatan kepala rumah tangga adalah sebagai berikut:

$$
\begin{aligned}
\text { income }_{i}= & \alpha+\beta H S_{i} \\
& +\sum_{k} \gamma_{k} X_{i k}+\varepsilon_{i}
\end{aligned}
$$

Variabel bebas utama yang digunakan pada persamaan 14 yaitu berupa variabel gangguan kesehatan yang dialami oleh kepala rumah tangga $\left(H S_{i}\right)$ dan diduga secara langsung mempengaruhi pendapatan kepala rumah tangga $\left(\right.$ income $\left._{i}\right)$. Variabel gangguan kesehatan didefinisikan sebagai akumulasi dari lama hari terganggunya aktifitas sehari-hari karena gangguan kesehatan yang dialami kepala rumah tangga pada tahun 2012 dan tahun 2013. Dengan asumsi bahwa, kejadian gangguan kesehatan yang terjadi berulang yang dialami oleh kepala rumah tangga mengindikasikan bahwa gangguan kesehatan yang dialami merupakan gangguan kesehatan serius yang dapat mempengaruhi pendapatan yang bisa dihasilkan oleh kepala rumah tangga.

Selain variabel gangguan kesehatan, karakteristik yang melekat pada kepala rumah tangga juga dapat mempengaruhi tingkat pendapatannya, sehingga dapat digunakan sebagai variabel kontrol pada persamaan pendapatan kepala rumah tangga $\left(X_{i k}\right)$. Diantara adalah umur, jenis kelamin, tingkat pendidikan (lama sekolah), lapangan usaha dimana kepala rumah tangga bekerja (pertanian, industri dan jasa), apakah kepala rumah tangga pernah mengalami pindah pekerjaan dalam satu tahun terakhir, kepemilikan jaminan kesehatan dan jumlah anak yang dimiliki.

Selain itu, persamaan ini juga menggunakan variabel interaksi antara gangguan kesehatan dan jenis kelamin dan variabel interaksi antara gangguan kesehatan dan kepemilikan jaminan kesehatan. Kedua variabel ini untuk menangkap perbedaan dampak dari gangguan kesehatan berdasarkan jenis kelamin dan kepemilikan jaminan kesehatan terhadap tingkat pendapatan kepala rumah tangga.

Selain karakteristik kepala rumah tangga, persamaan ini juga menggunakan variabel lokasi tempat tinggal (desa/kota) dan diwilayah mana kepala rumah tangga tersebut tinggal (berdasarkan pulau besar yang ada diIndonesia). Variabel ini selain untuk mengontrol perubahan yang terjadi pada level agregat/tingkat wilayah, yang juga dapat mempengaruhi pendapatan rumah tangga seperti pertumbuhan ekonomi, perubahan infrastruktur atau perubahan faktor lingkungan (Genoni, 2012) namun juga dapat menangkap perbedaan kondisi pasar tenaga kerja pada setiap wilayah.

\section{Persamaan Konsumsi Rumah Tangga}

Berdasarkan hasil estimasi pada persamaan (14), maka tahap selanjutnya adalah estimasi dampak perubahan pendapatan tersebut terhadap konsumsi rumah tangga. Pada tahap estimasi tingkat konsumsi rumah tangga ini, variabel bebas utama yang digunakan adalah variabel pendapatan hasil estimasi (predicted value) secara parsial dari persamaan (14), yaitu dengan hanya menggunakan variabel gangguan kesehatan, tidak termasuk variabel kontrol individu dan wilayah maupun variabel interaksi lainnya. Sehingga variabel estimasi pendapatan tersebut menggambarkan tingkat pendapatan yang dipengaruhi oleh gangguan kesehatan yang dialami oleh kepala rumah tangga (Arends-Kuenning, et al. 2019). Dengan metode ini, maka perubahan tingkat konsumsi yang terjadi didalam rumah tangga terjadi karena perubahan tingkat pendapatan yang disebabkan oleh gangguan kesehatan yang dialami oleh kepala rumah tangga. Sehingga persamaan konsumsi rumah tangga adalah sebagai berikut:

$$
\begin{aligned}
\text { Cons }_{i l}= & \alpha_{l}+\beta \text { in } \widehat{\operatorname{com}} e_{\imath}+ \\
& \sum_{k} \delta_{k} X_{i k}+\varepsilon_{i}
\end{aligned}
$$

Dimana Cons $_{\text {il }}$ adalah porsi (share) pengeluaran rumah tangga untuk kelompok pengeluaran ke- $l$ yang terdiri dari pengeluaran konsumsi pangan, non pangan (selain kesehatan) dan pengeluaran 
kesehatan, terhadap total pengeluaran rumah tangga pada rumah tangga ke- $i$. Penggunaaan porsi pengeluaran rumah tangga khususnya porsi pengeluaran untuk konsumsi pangan, dapat digunakan sebagai pendekatan tidak langsung untuk tingkat kesejahteraan rumah tangga (Muellbauer, 1980). Perubahan porsi pengeluaran untuk konsumsi pangan dan konsumsi non pangan dapat menggambarkan bagaimana pengaruh fluktuasi pendapatan yang dialami oleh rumah tangga terhadap tingkat kesejahteraan mereka.

Dari persamaan (15) diketahui bahwa $\sum_{l}$ Cons $_{l}=1$ untuk setiap rumah tangga ke-i. Sehingga perubahan porsi pengeluaran pada suatu kelompok pengeluaran maka akan mempengaruhi perubahan porsi pada kelompok pengeluaran yang lain. Karena itu sebagai suatu sistem persamaan, maka hubungan antar persamaan pada persamaan konsumsi rumah tangga akan terjadi pada adanya korelasi antar galat (error). Oleh karena itu berdasarkan pada hal ini maka, estimasi persamaan (15) dilakukan dengan menggunakan metode Seemingly Unrelated Regression Estimation (SURE). Model SURE merupakan suatu sistem persamaan linear yang terdiri dari beberapa persamaan dimana galat (error) antar persamaan tersebut memiliki korelasi. Menurut (Faharudin, Mulyana, etc. 2015), untuk mengestimasi persamaan (15) dip erlukan retriksi parameter agar konsisten dengan teori utilitas, retriksi tersebut yaitu:

$\sum_{l} \boldsymbol{\alpha}_{l}=1 ; \sum_{l} \boldsymbol{\beta}_{l}=\mathbf{0} ; \sum_{l} \boldsymbol{\delta}_{k l}=\mathbf{0}$

Sehingga dengan restriksi ini maka jika terdapat $n$ persamaan dalam suatu sistem persamaan, maka persamaan yang diestimasi hanya sebanyak $n$ - 1 persamaan (Poi, 2002).

Selain dipengaruhi oleh variabel tingkat pendapatan, tingkat konsumsi rumah tangga juga dipengaruhi oleh faktorfaktor lain $\left(X_{i k}\right)$, yaitu jumlah anggota rumah tangga, yang dapat menggambarkan beban yang harus ditanggung oleh rumah tangga (Faharuddin, et.al. 2015), apakah terdapat anggota rumah tangga lansia diatas 60 tahun dan anak usia kurang dari lima belas tahun (Nguyet \& Mangyo, 2010). Dimana keduanya selain merupakan tanggungan dari kepala rumah tangga namun kuantitas konsumsi keduanya yang relatif berbeda didalam rumah tangga dapat mempengaruhi tingkat konsumsi rumah tangga. Selain itu, pendapatan dari anggota rumah tangga yang lain juga dapat mempengaruhi tingkat konsumsi rumah tangga. Ketika pendapatan kepala rumah tangga menurun karena gangguan kesehatan yang dialami, pendapatan dari anggota rumah tangga yang lain dapat digunakan untuk memenuhi konsumsi rumah tangga. Kemudian variabel tingkat harga kesehatan. Dalam hal ini, menggunakan indeks harga sektor kesehatan tahun 2013 untuk semua propinsi di Indonesia dari BPS. Variabel ini dapat mempengaruhi tingkat konsumsi rumah tangga karena terkait dengan besarnya biaya kesehatan yang harus dikeluarkan ketika gangguan kesehatan terjadi.

\section{HASIL DAN ANALISA}

\section{Estimasi Pendapatan Kepala Rumah Tangga}

Tabel 1 dan tabel 2 dibawah ini menyajikan hasil estimasi dampak gangguan kesehatan yang dialami oleh kepala rumah tangga terhadap tingkat pendapatan ril perbulan kepala rumah tangga. Hasilnya diketahui bahwa gangguan kesehatan berdampak negatif dan signifikan mempengaruhi tingkat pendapatan ril perbulan kepala rumah tangga. Satu hari kepala rumah tangga mengalami gangguan kesehatan dapat menurunkan pendapatan ril perbulan sebesar 3,5 persen.

Dari hasil estimasi pada tabel 1 , juga dapat dilihat bahwa kepala rumah tangga yang bekerja di sektor pertanian merasakan dampak negatif yang lebih besar terhadap tingkat pendapatannya ketika mengalami gangguan kesehatan dibandingkan dengan kepala rumah tangga yang bekerja pada sektor industri dan sektor jasa. Hal ini dapat dilihat dari nilai koefisien dari variabel dummy sektor lapangan usaha untuk sektor industri dan jasa yang bertanda positif dan signifikan. Hal ini menunjukkan bahwa 
Tabel 1. Dampak Gangguan Kesehatan Terhadap Tingkat Pendapatan Ril Kepala Rumah Tangga

\begin{tabular}{lc}
\hline \multicolumn{1}{c}{ Variabel Bebas } & $\begin{array}{c}\text { Variabel Terikat } \\
\text { Pendapatan Ril } \\
\text { Kepala Rumah } \\
\text { Tangga }\end{array}$ \\
\hline Observasi Seluruh Rumah Tangga & $-2.909^{* * *}$ \\
Constanta & $(1.060)$ \\
Lama Hari Gangguan Kesehatan (longterm13) & $-0.035^{* *}$ \\
Dummy Bekerja Di Sektor Industri (industri13) & $(0.013)$ \\
& $0.177^{*}$ \\
Dummy Bekerja Di Sektor Jasa (jasal3) & $(0.102)$ \\
Interaksi antara variabel gangguan kesehatan dan variabel & $0.276^{* * *}$ \\
kelamin (longJK) & $(0.087)$ \\
Interaksi antara variabel gangguan kesehatan dan variabel & $0.040^{* * *}$ \\
kepemilikan Jaminan Kesehatan (Longjamkes) & $(0.014)$ \\
\hline Stanis & 0.001 \\
& \\
\hline
\end{tabular}

- Standard error didalam kurung

- $\quad * * * p<0.01, * * p<0.05, * p<0.1$

Tabel 2. Dampak Gangguan Kesehatan Terhadap Tingkat Pendapatan Ril Kepala Rumah Tangga Menurut Jenis Kelamin dan Kelompok Pendapatan

\begin{tabular}{lc}
\hline Variabel Bebas & Variabel Terikat \\
(Lama Hari Gangguan Kesehatan) & Pendapatan \\
\hline Rub Group 1 (Jenis Kelamin KRT) & Kepala Rumah Tangga \\
\hline KRT Laki-Laki & 0.005 \\
KRT Perempuan & $(0.004)$ \\
& $-0.040^{* * *}$ \\
Sub Group 2 (Kelompok Pendapatan) & $(0.012)$ \\
Kwartil 1 & $-0.024^{*}$ \\
Kwartil 2 & $(0.013)$ \\
Kwartil 3 & 0.020 \\
& $(0.045)$ \\
Kwartil 4 & -0.014 \\
& $(0.031)$ \\
\hline
\end{tabular}

\footnotetext{
- Standard error didalam kurung

$* * * \mathrm{p}<0.01, * * \mathrm{p}<0.05, * \mathrm{p}<0.1$
}

secara rata-rata tingkat pendapatan kepala rumah tangga yang bekerja pada sektor industri dan sektor jasa lebih tinggi dibandingkan kepala rumah tangga yang bekerja pada sektor pertanian, ketika mereka mengalami gangguan kesehatan.

Gangguan kesehatan tentu akan menyebabkan penurunan produktifitas dalam bekerja. Fakta miris sektor pertanian di Indonesia, mulai dari produktifitas yang rendah karena kepemilikan lahan yang relatif sempit (petani gurem), petani berusia lanjut, sistem pertanian yang masih tradisional dan tingkat pendapatan yang rendah semakin memperburuk kondisi ini. Sehingga sangat wajar ketika rumah tangga mengalami guncangan pendapatan akibat gangguan kesehatan, maka dampak yang dirasakan pada sektor pertanian akan lebih besar dibandingkan dengan sektor lainnya 
seperti sektor industri dan sektor jasa. Nguyet \& Mangyo (2010) dalam penelitiannya juga menemukan bahwa dampak negatif gangguan kesehatan terhadap pendapatan rumah tangga pertanian lebih besar dibandingkan dengan rumah tangga non pertanian.

Dari tabel 1 juga bisa diketahui bahwa kepemilikan jaminan kesehatan tidak berpengaruh signifikan terhadap tingkat pendapatan kepala rumah tangga ketika mengalami gangguan kesehatan. Hal ini karena masih sedikitnya rumah tangga yang memiliki jaminan kesehatan pada tahun 2013. Pada saat itu, sistem jaminan kesehatan masih belum terintegrasi dibawah koordinasi BPJS. Sehingga partisipasi masyarakat dalam keanggotaan jaminan kesehatan pada masih sangat rendah. Karena itu manfaat dari adanya jaminan kesehatan tersebut belum dapat dirasakan secara luas dimasyarakat.

Selain itu, dari tabel 1 juga bisa dilihat bahwa, kepala rumah tangga laki-laki yang mengalami gangguan kesehatan terkena dampak penurunan pendapatan yang lebih rendah dari pada kepala rumah tangga perempuan. Hasil ini juga semakin diperkuat oleh hasil estimasi yang dihasilkan ketika observasi kepala rumah tangga dibedakan berdasarkan jenis kelamin sebagaimana yang ditampilkan pada tabel 2 berikut ini.

Berdasarkan tabel 2 diatas terlihat bahwa dampak gangguan kesehatan hanya berpengaruh negatif dan signifikan terhadap pendapatan ketika kepala rumah tangga adalah perempuan. Sedangkan pada rumah tangga laki-laki dampak tersebut tidak berpengaruh signifikan. Menurut laporan World Bank (2013), umumnya rumah tangga dengan kepala rumah berjenis kelamin perempuan (RTP) merupakan rumah tangga miskin dan hanya memiliki satu orang dewasa pencari nafkah (single earner).

Fakta ini sejalan dengan data BPS pada tabel 3 dibawah ini yang menunjukkan bahwa rumah tangga dengan kepala rumah tangga perempuan sebagian besar berstatus tidak memiliki pasangan, baik karena cerai hidup atau cerai mati. Sehingga sebagai single parent dan single earner, kepala rumah tangga perempuan tersebut harus menjalankan fungsi ganda yaitu sebagai pencari nafkah juga sebagai pengurus rumah tangga.

Kondisi ini diperparah dengan ratarata usia mereka yang relatif tua, sehingga secara fisik memiliki kondisi tubuh yang lebih rentan untuk mengalami gangguan kesehatan. Sehingga, ketika gangguan kesehatan terjadi menimpa mereka, maka tidak ada anggota rumah tangga lain yang dapat menggantikan posisinya untuk bekerja sebagai kompensasi penurunan penawaran kerja tersebut. Karena itu kejadian gangguan kesehatan yang dialami menyebabkan penurunan pendapatan yang signifikan pada rumah tangga perempuan dibandingkan dengan rumah tangga lakilaki.

Hasil estimasi pada tabel 2 juga menunjukkan bahwa, jika dilihat berdasarkan kelompok pendapatan, maka pendapatan rumah tangga yang berada pada kwartil pertama akan mengalami dampak negatif yang signifikan akibat gangguan

Tabel 3. Persentase Rumah Tangga menurut Kelompok Umur, Jenis Kelamin Kepala Rumah Tangga, dan Status Perkawinan Tahun 2013

\begin{tabular}{lcccc|cccc}
\hline Kelompok & \multicolumn{4}{c|}{ Perempuan } & \multicolumn{4}{c}{ Laki-Laki } \\
\cline { 2 - 9 } Umur RT & $\begin{array}{c}\text { Belum } \\
\text { kawin }\end{array}$ & Kawin & $\begin{array}{c}\text { Cerai } \\
\text { hidup }\end{array}$ & $\begin{array}{c}\text { Cerai } \\
\text { mati }\end{array}$ & $\begin{array}{c}\text { Belum } \\
\text { kawin }\end{array}$ & Kawin & $\begin{array}{c}\text { Cerai } \\
\text { hidup }\end{array}$ & $\begin{array}{c}\text { Cerai } \\
\text { mati }\end{array}$ \\
\hline $10-24$ & 83.17 & 10.84 & 5.53 & 0.46 & 40.94 & 58.33 & 0.69 & 0.05 \\
$25-44$ & 10.83 & 31.92 & 27.22 & 30.03 & 2.39 & 96.06 & 1.08 & 0.47 \\
$45-59$ & 2.58 & 8.36 & 16.05 & 73.02 & 0.54 & 95.40 & 1.19 & 2.86 \\
$60+$ & 1.11 & 1.91 & 5.52 & 91.46 & 0.35 & 87.33 & 0.97 & 11.35 \\
\hline Total & 7.12 & 10.32 & 13.40 & 69.16 & 2.25 & 93.73 & 1.09 & 2.92 \\
\hline
\end{tabular}

Sumber: BPS 
Tabel 4. Persentase Rumah Tangga menurut Status/Kedudukan Dalam Pekerjaan Utama dan Kelompok Pendapatan Tahun 2013

\begin{tabular}{lcccc}
\hline \multirow{2}{*}{ Status/Kedudukan Dlm Pekerjaan Utama } & \multicolumn{4}{c}{ Kwartil Pendapatan } \\
\cline { 2 - 5 } & $\mathbf{1}$ & $\mathbf{2}$ & $\mathbf{3}$ & $\mathbf{4}$ \\
\hline Berusaha sendiri & 28.25 & 26.08 & 26.78 & 18.27 \\
Berusaha dibantu buruh tdk tetap/tdk bayar & 32.09 & 32.91 & 22.79 & 18.14 \\
Berusaha dibantu buruh tetap/dibayar & 2.14 & 3.28 & 4.32 & 11.38 \\
Buruh/karyawan/pegawai & 15.76 & 22.73 & 34.91 & 49.32 \\
Pekerja bebas & 20.55 & 13.46 & 10.15 & 2.28 \\
Pekerja keluarga/tdk dibayar & 1.20 & 1.53 & 1.05 & 0.62 \\
\hline Total & 100 & 100 & 100 & 100 \\
\hline
\end{tabular}

\section{Sumber: BPS}

kesehatan yang terjadi pada kepala rumah tangga. Satu hari kepala rumah tangga mengalami gangguan kesehatan akan menurunkan pendapatan ril perbulan sebesar 2,4 persen. Sebagaimana diketahui, rumah tangga pada kwartil pertama ini merupakan rumah tangga miskin, dan umumnya merupakan rumah tangga perempuan miskin dan hanya memiliki satu orang dewasa pencari nafkah (single earner). Maka dari itu dampak negatif dari gangguan kesehatan yang dialami oleh kepala rumah tangga akan berpengaruh signifikan terhadap tingkat pendapatannya. Sedangkan bagi rumah tangga pada kwartil kedua dan ketiga, tidak ada pengaruh yang signifikan terhadap tingkat pendapatan kepala rumah tangga ketika mengalami gangguan kesehatan.

Sedangkan bagi rumah tangga pada kwartil keempat yaitu rumah tangga dengan tingkat pendapatan yang lebih tinggi, maka satu hari gangguan kesehatan yang dialami oleh kepala rumah tangga akan menyebabkan penurunan pendapatan sebesar 8,3 persen. Sebagian besar kepala rumah tangga pada kwartil keempat ini merupakan buruh/pegawai. Sehingga ketika mereka tidak dapat bekerja karena gangguan kesehatan yang dialami maka mereka akan menerima konsekuensi berupa pemotongan pendapatan dari tempat mereka bekerja yang menyebabkan pendapatan mereka menjadi menurun.

\section{Estimasi Tingkat Konsumsi Rumah Tangga}

Berdasarkan hasil estimasi dampak gangguan kesehatan terhadap tingkat pendapatan kepala rumah tangga sebelumnya, diketahui bahwa secara umum gangguan kesehatan berdampak negatif terhadap tingkat pendapatan kepala rumah tangga. Selanjutnya dengan menggunakan hasil estimasi tersebut, maka akan dilihat bagaimana dampak penurunan pendapatan tersebut terhadap konsumsi rumah tangga.

Dengan menggunakan metode seemingly unrelated regression, tabel 5 dibawah ini menunjukkan arah hubungan dan besarnya dampak perubahan tingkat pendapatan kepala rumah tangga ketika mengalami gangguan kesehatan terhadap porsi pengeluaran untuk konsumsi pangan dan non pangan rumah tangga.

Berdasarkan tabel 5 berikut, terlihat bahwa penurunan pendapatan akibat gangguan kesehatan yang dialami oleh kepala rumah tangga akan menyebabkan penurunan porsi pengeluaran untuk konsumsi non pangan rumah tangga. Dalam hal ini, penurunan satu persen pendapatan rumah tangga karena gangguan kesehatan akan menurunkan porsi pengeluaran untuk konsumsi non makanan sebesar 5,3 persen.

Sedangkan untuk konsumsi pangan, hasil estimasi menunjukkan bahwa tidak ada pengaruh yang signifikan terhadap porsi pengeluaran untuk konsumsi pangan rumah tangga akibat penurunan pendapatan tersebut. Pola yang sama juga terjadi jika estimasi dilakukan pada rumah tangga perempuan dan rumah tangga pada kwartil pertama dan kwartil keempat. Yaitu penurunan pendapatan yang disebabkan oleh gangguan kesehatan yang dialami oleh kepala rumah tangga yang berjenis kelamin perempuan dan rumah tangga yang berada pada kwartil pertama dan keempat, rasio pengeluaran untuk konsumsi non pangan 
Tabel 5. Dampak Perubahan Tingkat Pendapatan Akibat Gangguan Kesehatan Terhadap Rasio Pengeluaran Konsumsi Pangan dan Non Pangan Rumah Tangga (\%)

\begin{tabular}{ccc}
\hline $\begin{array}{c}\text { Variabel Bebas } \\
\text { Estimasi Tingkat } \\
\text { Pendapatan) }\end{array}$ & \multicolumn{2}{c}{ Variabel Terikat } \\
\cline { 2 - 3 } & Rasio Pengeluaran Pangan & $\begin{array}{c}\text { Rasio Pengeluaran Non } \\
\text { Pangan }\end{array}$ \\
\hline Seluruh Rumah Tangga & -0.001 & $0.053^{* * *}$ \\
Sub Group (Berdasarkan Jenis Kelamin KRT) & $(0.008)$ & \\
KRT Laki-Laki & 0.006 & $-0.373^{* * *}$ \\
& $(0.059)$ & $(0.063)$ \\
KRT Perempuan & $(0.001)$ & $0.047 * * *$ \\
& $(0.007)$ & $(0.008)$ \\
Sub Group (Kelompok Pendapatan) & & $0.062^{* * *}$ \\
Kwartil 1 & 0.014 & $(0.023)$ \\
& $(0.021)$ & $-0.050^{*}$ \\
Kwartil 2 & $(0.030)$ & $(0.028)$ \\
& $(0.026)$ & $0.120^{* * *}$ \\
Kwartil 3 & $(0.004)$ & $(0.037)$ \\
& $(0.035)$ & $0.038^{* * *}$ \\
Kwartil 4 & 0.002 & $(0.012)$ \\
\hline
\end{tabular}

- Standard error didalam kurung

- $* * * \mathrm{p}<0.01, * * \mathrm{p}<0.05, * \mathrm{p}<0.1$

- Hasil estimasi pada rumah tangga dg KRT laki-laki dan rumah tangga pada kwartil 2 dan 3, meskipun menunjukkan hasil yang signifikan, namun karena hasil estimasi pada persamaan pendapatan kepala rumah tangga menunjukkan hasil yang tidak signifikan, maka pada dasarnya hasil estimasi ini juga tidak signifikan sehingga tidak bisa dianalisis lebih lanjut.

akan menurun, sedangkan rasio pengeluaran untuk konsumsi pangan tidak terkena dampak oleh penurunan pendapatan tersebut.

Hasil ini menunjukkan bahwa komoditas pangan sifatnya tidak elastis terhadap perubahan pendapatan. Sebagaimana hukum Engel juga menyatakan bahwa nilai elastisitas komoditas pangan akan terletak diantara 0 dan 1. Karena merupakan kebutuhan dasar bagi manusia, maka perubahan yang terjadi pada tingkat pendapatan tidak memberikan dampak berarti terhadap perubahan tingkat konsumsi pangan. Artinya bahwa, ketika terjadi fluktuasi pendapatan yang dialami oleh rumah tangga, misalnya karena gangguan kesehatan maka rumah tangga akan lebih memilih untuk mempertahankan tingkat konsumsi pangannya dengan cara mengurangi porsi pengeluaran untuk konsumsi non pangan.

Kemudian jika ditelisik lebih jauh, tabel 6 dibawah ini menunjukkan komoditas non pangan yang mengalami perubahan karena penurunan pendapatan akibat gangguan kesehatan yang dialami oleh kepala rumah tangga . Terlihat bahwa penurunan porsi pengeluaran konsumsi non pangan terjadi pada pengeluaran untuk perawatan dan pemeliharan rumah (termasuk biaya sewa/kontrak rumah), sedangkan pengeluaran untuk peralatan kebersihan, perawatan tubuh dan kebutuhan sehari lainnya (misal: sabun cuci/mandi, surat kabar, alat tulis, kosmetik dll) justru mengalami peningkatan. Hal ini diduga terjadi karena adanya peningkatan pengeluaran untuk barang-barang yang terkait dengan perawatan kesehatan bagi kepala rumah tangga yang sedang mengalami gangguan kesehatan.

Sedangkan pengeluaran untuk sumber energi dan telekomunikasi serta pengeluaran untuk pendidikan dan transportasi tidak terpengaruh oleh penurunan pendapatan akibat gangguan kesehatan . Hasil estimasi yang sama juga diperoleh pada sub sampel rumah tangga perempuan dan rumah tangga yang berada 
Tabel 6. Dampak Perubahan Tingkat Pendapatan Akibat Gangguan Kesehatan Terhadap Rasio Pengeluaran Konsumsi Non Pangan Rumah Tangga (\%)

\begin{tabular}{|c|c|c|c|c|}
\hline \multirow{2}{*}{$\begin{array}{c}\text { Variabel Bebas } \\
\text { Estimasi } \\
\text { Tingkat } \\
\text { Pendapatan) }\end{array}$} & \multicolumn{4}{|c|}{ Pengeluaran Konsumsi Non Pangan (Selain Kesehatan) } \\
\hline & $\begin{array}{c}\text { Perawatan dan } \\
\text { Pemeliharaan } \\
\text { Rumah }\end{array}$ & $\begin{array}{l}\text { Sumber Energi, Pos } \\
\text { dan Telekomunikasi }\end{array}$ & $\begin{array}{l}\text { Perawatan } \\
\text { Tubuh }\end{array}$ & $\begin{array}{c}\text { Pendidikan dan } \\
\text { Transportasi }\end{array}$ \\
\hline \multicolumn{5}{|l|}{ Sub Sampel } \\
\hline \multirow{2}{*}{$\begin{array}{l}\text { Seluruh } \\
\text { Tangga }\end{array}$} & $0.018^{*}$ & 0.000 & $-0.008 * * *$ & 0.007 \\
\hline & $(0.010)$ & $(0.006)$ & $(0.003)$ & $(0.009)$ \\
\hline \multirow{2}{*}{$\begin{array}{l}\text { Rumah Tangga } \\
\text { Perempuan }\end{array}$} & $0.016^{*}$ & 0.000 & $-0.007 * * *$ & 0.006 \\
\hline & $(0.008)$ & $(0.005)$ & $(0.003)$ & $(0.008)$ \\
\hline \multirow{2}{*}{$\begin{array}{l}\text { RumahTangga } \\
\text { Kwartil Pertama }\end{array}$} & $0.054^{* *}$ & -0.002 & $-0.015^{*}$ & -0.014 \\
\hline & $(0.026)$ & $(0.018)$ & $(0.009)$ & $(0.025)$ \\
\hline \multirow{2}{*}{$\begin{array}{l}\text { Rumah Tangga } \\
\text { Kwartil } 4\end{array}$} & 0.005 & $0.014 *$ & 0.004 & 0.007 \\
\hline & $(0.013)$ & $(0.008)$ & $(0.004)$ & $(0.013)$ \\
\hline
\end{tabular}

Standard errors are in parenthesis

$* * * \mathrm{p}<0.01, * * \mathrm{p}<0.05, * \mathrm{p}<0.1$

pada kwartil pertama. Sedangkan untuk rumah tangga di kwartil keempat, penurunan pengeluaran non pangan terjadi pada pengeluaran energi dan telekomunikasi (misal: bahan bakar, air, telekomunikasi dll). Sedangkan untuk pengeluaran non pangan yang lain tidak terpengaruh oleh adanya penurunan pendapatan akibat gangguan kesehatan yang terjadi.

\section{KESIMPULAN DAN SARAN}

Gangguan kesehatan yang dialami
oleh kepala rumah tangga akan menyebabkan penurunan tingkat pendapatan ril perbulan. Penurunan pendapatan ini akan lebih dirasakan oleh rumah tangga yang berada pada kelompok pendapatan terendah, dengan kepala rumah tangga berjenis kelamin perempuan. Kepala rumah tangga yang bekerja pada sektor pertanian juga akan merasakan dampak yang lebih besar dibandingkan dengan kepala rumah tangga yang bekerja pada sektor industri dan jasa.

Akibat penurunan pendapatan kepala rumah tangga tersebut, maka rumah tangga akan menurunkan porsi pengeluaran konsumsi untuk non pangan. Sedangkan

porsi pengeluaran untuk pangan tidak terdampak oleh adanya penurunan pendapatan akibat gangguan kesehatan tersebut. Artinya ketika pendapatan menurun, rumah tangga akan berusaha untuk menjaga tingkat konsumsi pangannya dengan cara menurunkan pengeluaran untuk konsumsi non pangan.

Perubahan pengeluaran konsumsi untuk non pangan tersebut terjadi untuk pengeluaran perawatan dan pemeliharaan rumah yang semakin menurun. Sedangkan pengeluaran untuk perawatan tubuh cenderung meningkat, yang dilakukan untuk memenuhi kebutuhan untuk barangbarang yang diperlukan untuk perawatan kesehatan bagi kepala rumah tangga yang sakit. Sementara itu, pengeluaran untuk pendidikan dan transportasi serta pengeluaran untuk kebutuhan sumber energi dan telekomunikasi tidak terpengaruh oleh adanya penurunan pendapatan akibat gangguan kesehatan yang dialami oleh kepala rumah tangga.

Beberapa keterbatasan penelitian ini diantaranya yaitu pertama, periode penelitian ini menggunakan data tahun 2013, yang dirasa sudah terlalu lama (out of date). Sehingga kurang bisa 
menggambarkan kondisi terkini yang bisa sangat berbeda. Meskipun hal ini terjadi karena ketersediaan data panel tahunan yang terbatas. Kedua yaitu lemahnya ukuran gangguan kesehatan yang digunakan sehingga tidak dapat menangkap dengan baik tingkat keparahan dari gangguan kesehatan yang dialami oleh kepala rumah tangga, yang mungkin akan memberikan dampak yang berbeda terhadap pendapatan dan konsumsi rumah tangga. Yang terakhir yaitu, penelitian ini juga belum mempertimbangkan gangguan kesehatan yang terjadi pada anggota rumah tangga yang lain baik yang memiliki kontribusi terhadap pendapatan rumah tangga maupun yang tidak. Dimana hal ini bisa saja turut mempengaruhi pendapatan dan konsumsi rumah tangga.

Karena itu untuk penelitian berikutnya disarankan untuk menggunakan data yang terbaru yang lebih dapat menggambarkan kondisi terkini. Kemudian dengan menggunakan definisi gangguan kesehatan yang dapat menangkap derajat keparahan dari gangguan kesehatan yang terjadi tidak hanya pada kepala rumah tangga namun juga pada anggota rumah tangga lain, baik yang memiliki kontribusi terhadap pendapatan rumah tangga atau tidak. Sehingga diharapkan bisa melengkapi studi-studi empiris yang sudah ada sebelumnya.

Sedangkan bagi perumus kebijakan, kebijakan yang dapat melindungi kesejahteraan rumah tangga ketika mereka mengalami gangguan kesehatan harus lebih ditingkatkan, khususnya pada rumah tangga miskin disektor pertanian dan dengan kepala rumah tangga perempuan. Mengingat dampak negatif akibat gangguan kesehatan terhadap kesejahteraan yang dirasakan oleh rumah tangga tersebut lebih besar. Misalnya dalam bentuk subsidi langsung biaya pengobatan atau dalam bentuk cash transfer. Sehingga melalui kebijakan tersebut dapat mencegah penurunan kesejahteraan rumah tangga akibat penurunan pendapatan atau peningkatan pengeluaran akibat gangguan kesehatan yang dialami.

\section{DAFTAR PUSTAKA}

Arends-Kuenning, M., Baylis, K., \& Garduño-Rivera， R. (2019). The effect of NAFTA on internal migration in Mexico: a regional economic analysis. Applied Economics, 51(10), 1052-1068. https://doi.org/10.1080/00036846.20 18.1524976

Asfaw, A., \& Braun, J. von. (2004). Is Consumption Insured against Illness? Evidence on Vulnerability of Households to Health Shocks in Rural Ethiopia. Economic Development and Cultural Change, 53(1), 115-129. https://doi.org/10.1086/423255

Ashenfelter, B. Y. O., \& Heckman, J. (1974). The Estimation of Income and Substitution Effects in a Model of Family Labor Supply. Econometrica, Vol. 42, No. 1 (Jan., 1974), Pp. 73-85, 42(1), 73-85.

Cochrane, J. H. (1991). A Simple Test of Consumption Insurance, 99(5), 957976.

Faharuddin, F., Mulyana, A., Yamin, M., \& Yunita Yunita. (2015). Nutrient elasticities of food consumption: the case of Indonesia. Journal of Agribusiness in Developing and Emerging Economies, 5(2), 57-75. https://doi.org/10.1108/JADEE-042017-0048

Faharudin, Mulyana, A., Yamin, M., \& Yunita. (2015). ANALISIS POLA KONSUMSI PANGAN DI SUMATERA SELATAN 2013: PENDEKATAN QUADRATIC ALMOST IDEAL DEMAND SYSTEM Analysis of Food Consumption Patterns in South Sumatra in 2013: A Quadratic Almost Ideal Demand System Approach.

Genoni, M. E. (2012). Health Shocks and Consumption Smoothing: Evidence from Indonesia. Economic Development and Cultural Change, 60(3), 475-506. https://doi.org/10.1086/664019

Gertler, P., \& Gruber, J. (2002). Insuring consumption against illness. 
American, The Review, Economic Database, Social Science.

Hoogeveen, J., Tesliuc, E., Vakis, R., \& Dercon, S. (2004). A Guide to the Analysis of Risk Vulnerability and Vulnerable Groups.

Kementerian Kesehatan Republik Indonesia. (2017). Profil Kesehatan Indonesia Tahun 2016. https://doi.org/10.1111/evo.12990

Maloney, T. (1987). Employment Constraints and the Labor Supply of Married Women A Reexamination of the Added Worker Effect. The Journal of Human Resources, 22(1), 51-61.

https://doi.org/10.2307/145866

Muellbauer, A. D. and J. (1980). An Almost Ideal Demand System. American Economic Association An, 70(2-3), 312-326.

https://doi.org/S0277-

9536(13)00479-6

[pii]\r10.1016/j.socscimed.2013.08.0 27

Nguyet, N. T. N., \& Mangyo, E. (2010). Vulnerability of households to health shocks: An Indonesian study. Bulletin of Indonesian Economic Studies, 46(2), 213-235. https://doi.org/10.1080/00074918.20 10.486108

Poi, B. P. (2002). From the Help Desk: Demand System Estimation. The Stata Journal: Promoting Communications on Statistics and Stata, 2(4), 403-410. https://doi.org/10.1177/1536867x020 0200406

Russell, S. (2004). The Economic Burden Of Illness For Households In Developing Countries: A Review Of Studies Focusing On Malaria, Tuberculosis, And Human Immunodeficiency Virus/Acquired Immunodeficiency Syndrome. The American Journal of Tropical Medicine and Hygiene, 71(2 suppl), 147-155. Retrieved from http://www.ajtmh.org/content/71/2_s uppl/147
Sparrow, R., Poel, E. Van De, Hadiwidjaja, G., Yumna, A., Warda, N., \& Suryahadi, A. (2014). Coping With The Economic Consequences Of Ill Health In Indonesia. Health Econ, 23(July 2013), 719-728. https://doi.org/10.1002/hec

Strauss, J., \& Thomas, D. (1998). Health , Nutrition , and Economic Development, 36(2), 766-817.

Townsend, R. M. (1994). Risk and Insurance in Village India Author. The Econometric Society, 62(3), 539591.

Wagstaff, A. (2007). The economic consequences of health shocks: Evidence from Vietnam. Journal of Health Economics, 26(1), 82-100. https://doi.org/10.1016/j.jhealeco.20 06.07.001

Wang, H., Zhang, L., \& Hsiao, W. (2006). Ill health and its potential influence on household consumptions in rural China. Health Policy, 78(2-3), 167177.

https://doi.org/10.1016/j.healthpol.20 05.09.008

Widyanti, W., Suryahadi, A., Sumarto, S., \& Yumna, A. (2010). The Relationship Between Chronic Poverty and Household Dynamics: Evidence from Indonesia. Ssrn, (January). https://doi.org/10.2139/ssrn.1537080

World Bank. (2013). Indonesia - Gender equality (English). Indonesia Gender policy brief; no. 1. Washington DC: World Bank. 